\title{
Is it all grist to the mill? Wandering between indications for psychoanalytic treatment and the analytic field
}

\author{
Caiu na rede é peixe? Entre as indicações de tratamento \\ psicanalítico e o campo analítico
}

\author{
Marina Bento Gastaud, ${ }^{1}$ Julia Domingues Goi, ${ }^{2}$ Ana Margareth Bassols, ${ }^{2}$ Camila Piva da Costa, ${ }^{3}$ \\ Daniela Krieger, ${ }^{3}$ Diogo Machado, ${ }^{4}$ Felipe Bauer Pinto da Costa, ${ }^{4}$ Jair Knijnik, ${ }^{5}$ Mariana Torres, ${ }^{5}$ Pricilla Braga, ${ }^{1}$ \\ Stefania Pigatto Teche ${ }^{4}$ Rafael Wellausen, ${ }^{1}$ Claudio Laks Eizirik ${ }^{2}$
}

\begin{abstract}
Determining the indications and contraindications for psychoanalytic treatment seems crucial to achieve therapeutic success and improve treatment effectiveness. In reviewing the classic literature on the topic, aspects such as age, diagnosis, motivation for treatment, present moment in life, ability to gain insight, psychic suffering when seeking treatment, defensive behaviors, and frustration tolerance are clearly analyzed by therapists/ analysts when indicating psychoanalytic treatments. However, traditionally, most criteria underlying such indications date back to a time when the therapeutic relationship was viewed merely as a therapist treating a patient, with no regard to the therapeutic relationship itself. The goal of this article was to critically review the relevance and current adequacy of indications for psychoanalytic treatment, in view of advancements in knowledge on the analytic field. Considering cases that do not evolve as expected according to the indications, patients who are better suited to certain therapists, and therapist-patient pairs that modify their interaction over the course of treatment, the main question remains on how to identify the necessary elements in evaluating a candidate patient for psychoanalytic treatment, as well as the significant elements of therapeutic action.
\end{abstract}

Keywords: Psychoanalysis, psychoanalytic psychotherapy, indication, contraindication, analytic field.

\section{Resumo}

Determinar critérios de indicação e contraindicação para tratamentos psicanalíticos parece um ponto técnico crucial para a obtenção de sucesso terapêutico e a elevação de seus índices de efetividade. Na revisão da literatura clássica sobre o tema, percebe-se que a idade, o diagnóstico do paciente, a motivação para tratamento, o momento de vida, a capacidade de insight, o sofrimento psíquico apresentado no momento da busca de tratamento, o estilo defensivo e a tolerância à frustração são alguns dos pontos analisados pelos terapeutas/analistas para indicar tratamentos psicanalíticos. Contudo, classicamente, tais indicações provêm de um período em que a relação terapêutica era vista meramente como um terapeuta atendendo um paciente, sem levar em conta a relação terapêutica propriamente dita. O objetivo deste artigo foi revisar criticamente a relevância e pertinência atual das indicações para tratamento psicanalítico, tendo em vista a evolução dos conhecimentos sobre o campo analítico. Considerando casos que não evoluem da maneira esperada segundo as indicações, pacientes que se adaptam melhor a determinados terapeutas e duplas que modificam sua interação ao longo do tempo de tratamento, a principal questão continua sendo como identificar quais seriam os elementos necessários na avaliação de um paciente candidato a tratamento psicanalítico, bem como os elementos significativos da ação terapêutica.

Descritores: Psicanálise, psicoterapia psicanalítica, indicação, contraindicação, campo analítico.

\footnotetext{
${ }_{1}^{1}$ Psychologist, Universidade Federal do Rio Grande do Sul (UFRGS), Porto Alegre, RS, Brazil. Centro de Estudos Luis Guedes (CELG), Porto Alegre, RS, Brazil. ${ }^{2}$ Psychiatrist, UFRGS. CELG. Associação de Psiquiatria do Rio Grande do Sul (APRS), Porto Alegre, RS, Brazil. Sociedade Psicanalítica de Porto Alegre (SPPA), Porto Alegre, RS, Brazil. ${ }^{3}$ Psychologist, UFRGS. ${ }^{4}$ Psychiatrist, UFRGS. CELG. APRS. ${ }^{5}$ Psychiatrist, CELG. APRS. SPPA.

The results described in this paper were presented at $25^{\circ}$ Ciclo de Avanços em Clínica Psiquiátrica, held at Associação de Psiquiatria do Rio Grande do Sul (APRS) on May 262012.

Financial support: none.

Submitted Jun 13 2012, accepted for publication Oct 04 2012. No conflicts of interest declared concerning the publication of this article.

Suggested citation: Gastaud MB, Goi JD, Bassols AM, da Costa CP, Krieger D, Machado D, et al. Is it all grist to the mill? Wandering between indications for psychoanalytic treatment and the analytic field. Trends Psychiatry Psychother. 2013;35(1):12-23.
} 


\section{Introduction}

The effectiveness of psychoanalytic psychotherapy has been demonstrated in different national ${ }^{1-4}$ and international ${ }^{5-10}$ studies, contributing to the development of evidence-based psychotherapy. ${ }^{11-13}$ However, the effectiveness of such therapies depends on the establishment of precise indication and contraindication criteria. ${ }^{14,15}$ Research has demonstrated that treatment dropout in psychoanalytic psychotherapy is a highly prevalent outcome, ${ }^{16}$ causing concern among psychotherapist of different schools. High indices of dropout may possibly be explained by the lack of precise indications for treatment. Indication and contraindication criteria therefore need to be revised, as they change over time with the modernization of therapeutic techniques. As a result, determining indication and contraindication criteria for psychoanalytic psychotherapy seems to be a crucial technical point in obtaining therapeutic success and improving treatment effectiveness.

The first attempts to determine the effectiveness of psychoanalytic therapies date back to the origins of psychoanalysis: on December 12, 1904, Freud delivered a lecture at a conference in the Medical University of Vienna and claimed that his new treatment modality would be indicated to what we now call neurosis and contraindicated for patients without a certain degree of culture and a somewhat reliable character. ${ }^{17}$ At the same conference, Freud warned that cases of psychosis, perversion, addiction, and psychopathy are always difficult to treat with psychoanalysis, and that the method is contraindicated in acute and emergency cases, especially anorexia nervosa. Freud based his indication and contraindication criteria on both the patient's condition (diagnosis) and individual characteristics (e.g. personality traits). According to Freud, patient age also posed limitations to the use of psychoanalytic therapy: people aged close to 50 years would lack the plasticity necessary to benefit from psychoanalytic psychotherapy.

As will be seen below, psychoanalytic literature has shown controversial findings in the determination of indication and contraindication criteria for analysis and psychoanalytic psychotherapy, leaving a gap that needs to be fulfilled by empirical data rather than theoretical speculation only. In this sense, Fonagy ${ }^{18}$ reviewed studies assessing the effectiveness of different treatment modalities and compared their effects on different psychopathologies. The author found that psychoanalytic psychotherapy shows less evidence of effectiveness than other psychotherapies in cases of schizophrenia, bipolar disorder in a manic episode, and anorexia nervosa. Fonagy emphasized that the absence of evidence for the indication of psychoanalytic treatment should not be confused with evidence of ineffectiveness, pointing to the need for investigators to focus their attention on this broad field of research.

The myth that any patient can be treated and healed with psychotherapy seems to be associated with difficulties and the protected market of psychotherapists in general, but can no longer be maintained. The progress of science and psychopharmacology, as well as treatment results currently observed, increasingly require psychotherapists to refine their evaluations and treatment indications. ${ }^{19}$ It is the therapist's responsibility to indicate the best treatment technique available for each patient, i.e., the one most likely to bring benefits in relieving the patient's suffering.

Notwithstanding, very often, the evaluation conducted at the beginning of treatment is insufficient to determine treatment prognosis. In addition to the patient's individual characteristics, variables related to the patient/therapist pair and to the interaction between them (the analytic field established, therapeutic alliance, transference/countertransference, ability to counteract resistance, etc.) are essential for the establishment of a successful therapeutic process and will become evident as treatment evolves.

Therefore, the objective of the present study was to describe the different criteria used for indication and contraindication of psychoanalytic therapy as found in the literature (summarized in Tables 1 and 2) and to discuss their clinical adequacy at present, based on recent advancements in the technique itself and its potential to reach different patients. The current emphasis on the analytic field is also taken into consideration as a determinant of treatment prognosis. 
Table 1 - Indication and contraindication criteria for analysis/psychoanalytic psychotherapy according to international authors

\begin{tabular}{ll}
\hline Author & Indications \\
\hline Freud $(1905)^{17}$ & Neuroses \\
Fenichel (1934) 20 & $\begin{array}{l}\text { Neurotic conflicts; patients with traces of } \\
\text { object relations. }\end{array}$ \\
& \\
Glover (1955) ${ }^{21}$ & $\begin{array}{l}\text { Neuroses with a matrix of hysteria; sexual } \\
\text { inhibitions with genital fixation; facultative } \\
\text { bisexuality (with a history of traumatic seduction } \\
\text { during the latent period, signs suggestive } \\
\text { of castration anxiety, and a protective but } \\
\text { pathological identification with the genitor of the } \\
\text { opposite sex); facultative moderate perversions } \\
\text { in a previously satisfactory marriage; occasional } \\
\text { anxiety; conversion symptoms; neurotic } \\
\text { social and professional inhibitions; reactive } \\
\text { depression (general complaints of dissatisfaction, } \\
\text { unhappiness, inability to feel well, inability to deal } \\
\text { with love feelings). } \\
\text { Severe neurotic disorders }\end{array}$ \\
& \\
& \\
& \\
& \\
&
\end{tabular}

Nacht \& Lebovici Severe neurotic disorders

$(1958)^{22}$

Dewald $(1973)^{23}$

Greenson $(1981)^{24}$

Kaplan \& Sadock $(1984)^{25}$

Etchegoyen $(2004)^{26}$ Severe neuroses

Gabbard (2006) $)^{27}$

Kernberg $(2006)^{28}$
Previous ability to establish and maintain emotionally significant bonds with other people; motivation; ability for introspection; flexibility of defensive behaviors; at least average intelligence; tolerance to anxiety and frustration; conflict centered on the phallic and oedipal phases; young adults; availability for a long-term, regular treatment; favorable economic conditions; family support.

Anxiety hysteria; conversion hysteria; obsessive compulsive neurosis; neurotic depression; character neurosis; psychosomatic conditions.

In psychoanalysis: unconscious conflicts resulting in signs, symptoms, or character problems; personality conflicts; previous failure of psychotherapy. In analytically oriented psychotherapy: mature personality; ability to establish a therapeutic alliance; tolerance to frustration and motivation, however with no indication for analysis.

Strong motivation to understand him/herself; suffering; regression at the service of the ego; frustration tolerance; ability to gain insight; intact reality test; reasonable control of impulses; ability to maintain a job; ability to think in terms of analogy and metaphor; reflexive responses to interpretation attempts; significant object relations.

For psychoanalysis, the strength of the ego, motivation, insight, introspection, and secondary gains should be considered, in addition to intelligence and age.

Contraindications

Comments

Absence of culture and a reliable character; psychosis, perversion, addiction, and psychopathy; acute and emergency cases (e.g. anorexia nervosa); patients aged $>50$ years.

Psychosis; narcissistic neuroses; mental retardation; unfavorable life conditions; neurosis of little importance; suicidal ideation; severe speech impairments; absence of a reasonable, cooperative ego; secondary gains with the disease.

Endogenous depression; manicdepressive psychosis; schizophrenia; psychotic personality; severe psychopathy.

Age above 40 years; neurotic disorders of moderate severity.

Use of primitive defenses; extremely rigid individuals or those without internalized values and rules; patients showing regressive decompensation. schizophrenia and manic-depressive psychosis.

In psychoanalysis: absence of a rational, cooperative ego; absence of minimum suffering to justify treatment; urgencies that do not allow to wait

; for the establishment of transference neurosis; unchangeable life conditions where treatment would become an even greater source of difficulty. In analytically oriented psychotherapy: no contraindications are mentioned.

Cases of psychosis, perversion, addiction, and psychopathies.

For psychoanalytic psychotherapy, secondary gains, the impossibility to control life-threatening or therapythreatening behaviors, limited intelligence, significant antisocial characteristics, and a desperate life situation.
The author specifically mentions analysis, relativizing some contraindications depending on motivation, resistance, flexibility, secondary gains, and desire to improve.

Indications exist, however with a doubtful prognosis, for cases showing sexual inhibitions with pregenital fixation, obsessive neurosis, fetishism, chemical dependence, psychopathic delinquency, and psychotic social and professional inhibitions.

The authors focus on analysis, arguing that neurotic disorders of moderate severity should be treated with short-term, simple psychotherapeutic methods or psychiatric pharmacology.

The author highlights therapist selfknowledge as an important factor to indicate psychoanalytic treatment.

Contraindications refer to insightoriented therapies, even though the author advocates the adequacy of support therapies for these cases.

The assessment of symptoms and personality structural diagnosis should be taken into consideration when indicating or contraindicating treatment, as well as healthy resources, motivations, and secondary gains.

The authors suggest a short period of experimental analysis in order to decide on the possibility to analyze each case.

The indication of the best approach (expressive or support) is dynamic. During crises or whenever the patient does not present indication criteria, the support approach should be used. Once the crisis is over, the expressive approach should be recovered.

Diagnosis (both structural and nosological) is essential to choose the best treatment indication. 
Table 2 - Indication and contraindication criteria for analysis/psychoanalytic psychotherapy according to Brazilian authors

\begin{tabular}{|c|c|c|c|}
\hline Author & Indications & Contraindications & Comments \\
\hline Zimerman $(2004)^{29}$ & $\begin{array}{l}\text { Accessibility to the patient's } \\
\text { unconscious. }\end{array}$ & $\begin{array}{l}\text { Mental retardation; absence of } \\
\text { minimum ability to abstract and } \\
\text { symbolize; unusual motivations. }\end{array}$ & $\begin{array}{l}\text { The accessibility criterion } \\
\text { focuses primarily on motivation, } \\
\text { availability, courage, and ability } \\
\text { to grant access to his/her } \\
\text { unconscious for the analyst and for } \\
\text { him/herself. }\end{array}$ \\
\hline $\begin{array}{l}\text { Keidann \& } \\
\text { Dal Zot }(2005)^{19}\end{array}$ & $\begin{array}{l}\text { Strong motivation to understand } \\
\text { him/herself; identification of the } \\
\text { psychological origin of symptoms; } \\
\text { significant suffering; frustration } \\
\text { tolerance; sufficient control of impulses; } \\
\text { preserved reality test; ability to regress } \\
\text { at the service of the ego; ability } \\
\text { to establish a therapeutic alliance; } \\
\text { reasonable ego strength; average } \\
\text { intelligence; availability of time and } \\
\text { financial resources. }\end{array}$ & $\begin{array}{l}\text { Acute psychotic conditions, } \\
\text { severe depression with multiple } \\
\text { suicide attempts, chronic alcohol } \\
\text { dependence or drug addiction, } \\
\text { phobias causing chronic disability, } \\
\text { borderline personality with strongly } \\
\text { aggressive or self-destructive } \\
\text { behaviors, organic brain syndrome } \\
\text { and mental deficiency, character } \\
\text { disorders and severe eating } \\
\text { disorders. }\end{array}$ & $\begin{array}{l}\text { In cases with contraindications, } \\
\text { psychoanalytic treatment } \\
\text { should be combined with other } \\
\text { strategies, e.g., support therapies, } \\
\text { behavioral therapies, use of } \\
\text { psychopharmacological drugs, or } \\
\text { hospital admission. }\end{array}$ \\
\hline $\begin{array}{l}\text { Eizirik \& Hauck } \\
(2007)^{30}\end{array}$ & $\begin{array}{l}\text { Personality disorders (obsessive, } \\
\text { avoidant, hysterical, and narcissistic); } \\
\text { spontaneous search for treatment; } \\
\text { time availability; professional activity; } \\
\text { intelligence; good previous adaptation; } \\
\text { reality test; quality object relation } \\
\text { in the past; realistic expectations; } \\
\text { psychic suffering; psychic curiosity; } \\
\text { psychological thinking; frustration } \\
\text { tolerance; identity diffusion; dependence } \\
\text { conflicts; inability to control impulses; } \\
\text { sense of responsibility; unidentifiable } \\
\text { focal conflict; motivation to change; } \\
\text { therapeutic alliance. }\end{array}$ & Antisocial personality disorder. & $\begin{array}{l}\text { The borderline disorder is } \\
\text { described as being subject } \\
\text { to treatment with modified } \\
\text { psychoanalytic interventions. }\end{array}$ \\
\hline
\end{tabular}

Many authors do not explicitly differentiate between indications for analysis and indications for psychoanalytic psychotherapy. It therefore seems relevant to emphasize that the objective of analytically-oriented psychotherapy would be to focus on the patient's current conflict, whereas psychoanalysis is aimed at elaborating on the primary conflict. ${ }^{30}$ To Kernberg, ${ }^{28}$ the focus of psychoanalysis would be on structural change - the integration of unconscious repressed or dissociated conflicts in the conscious ego -, whereas the objective of psychoanalytic psychotherapies would be the partial reorganization of the psychic structure within a context of significant symptomatic changes. Structure refers to the stable ordering of a subject's constant and essential metapsychological elements, e.g., the nature of mental anguish, the level of regression of libido and the ego, the relational mode, the nature of conflict, and major defenses. ${ }^{31}$ Structural change, according to this paradigm, refers to evolutive or involutive movements in the relationship between the elements that constitute that stable ordering system.

Therefore, indication and contraindication criteria for analysis and for psychoanalytic psychotherapy probably should distinct, as they influence the degree of regression to which the patient is subjected. For Kaplan \& Sadock, ${ }^{25}$ for example, because in psychotherapy no transference neurosis is developed, indications for this treatment would be broader than for psychoanalysis. In spite of these controversies, and because not all authors differentiate between one or another therapeutic approach, differences between analysis and psychoanalytic psychotherapy will only be separately discussed when the cited author has also done so.

\section{Patient characteristics}

\section{Age}

There has been an evolution regarding the consideration of patient age in the indication of psychoanalytic treatment over the theoretical history of psychoanalysis. The establishment of an age limit as a criterion for indicating psychoanalysis, as proposed by Freud, started to be reviewed by classic authors such as Abraham ${ }^{32}$ and Segal, ${ }^{33}$ whose studies proved the efficacy of psychoanalysis in patients aged over 50 years. Nacht \& Lebovici, ${ }^{22}$ in turn, accepted the age criterion defined by Freud and went further in establishing an even stricter limit for the patient to start analysis: 40 years. For Kernberg, ${ }^{28}$ advanced age should be carefully evaluated by the analyst when indicating this type of treatment, but is not a determinant of treatment failure.

In 1934, Fenichel ${ }^{20}$ argued that the ideal age range for starting analysis would be between 15 and 40 years, although the author did not discard the possibility of a successful treatment after this age limit, provided the patient shows some degree of personality flexibility 
and ability to reason. In the specific case of children, treatment would be more difficult because of the double resistance that the analyst has to face (both of the child and of parents), but this difficulty should not necessarily be seen as a contraindication. The real lower age limit would in fact be determined by the child's ability to talk.

For Dewald, ${ }^{23}$ young adults have a greater potential to implement the changes they deem necessary, whereas the insights of elderly people may cause depression, as there is less life time left to implement important changes. Adolescents, in turn, may often be less able to maintain an appropriate reflexive distance. In sum, Dewald does not advocate that age should be a contraindication, but recommends a careful examination of patients at lower or upper age limits.

As a result of the increasing evidence suggesting that analysis or psychoanalytic psychotherapy can benefit both children and the elderly, contemporary authors have abandoned the age limit criterion and removed it from the classic list of contraindications. $26,27,29,30$ Even though the elderly are less prone to receiving psychological treatment in general, some clinical trials have already been undertaken, especially with depressed patients, and have attested to the effectiveness of psychoanalytic psychotherapy in this population. ${ }^{34}$

\section{Diagnosis}

In our literature review, the following indication criteria were found: neuroses ${ }^{17,19,20-22,24,26,35-37}$; psychosomatic conditions ${ }^{24}$; sexual inhibitions (impotence and frigidity $)^{21}$; personality disorders, such as obsessive, avoidant, hysterical, narcissistic, and dependent ${ }^{30,38}$; depression and dysthymia $20,21,24,38$; generalized anxiety disorder, panic disorder, social phobia, and posttraumatic stress disorder. ${ }^{38}$

Psychoanalytic treatment would be contraindicated in the following cases: psychosis ${ }^{19-21,24,26}$; obsessive-compulsive disorder 38 ; perversions ${ }^{20,26}$ and antisocial personality ${ }^{21,26,30,38}$; addictions ${ }^{19,20,26 ;}$ severe depression (with suicide attempts) ${ }^{19}$; incapacitating phobias ${ }^{19}$; severe borderline personality ${ }^{19}$; organic brain syndrome/dementias ${ }^{19,29}$; cognitive deficitit ${ }^{19,23,28}$; severe dietary disorders. ${ }^{19}$

The criteria above are presented schematically for didactic purposes, as there is no consensus in the literature on the topic. Zetzel, ${ }^{36}$ for example, suggests that, within the same diagnostic condition, different indication and contraindication criteria may apply: some types of hysteria will probably respond better to analysis than other types, and the same is true of obsessive personality disorder. Dewald ${ }^{23}$ and Zimerman ${ }^{29}$ have also criticized the use of clinical diagnoses as indications for analysis and psychoanalytic psychotherapy, as some obsessive patients may have a worse prognosis than patients with psychotic reactions. ${ }^{29}$

For Fenichel, ${ }^{20}$ analysis is indicated to all patients with neurotic conflicts and contraindicated to those with conflicts related to a phase preceding the existence of objects, where an inability and disinterest in maintaining contact with other people may be present. There are exceptions, however, for psychotic cases that show traces of a good object relation, where the analyst may gradually promote readiness for psychoanalytic treatment. The same exception is valid for patients with schizoid personalities, where analysis can prevent future psychotic episodes. Certain complications can pose serious difficulties to the analysis of a hysterical patient and can make the analysis of a schizophrenic patient very easy. Each case has to be assessed individually in terms of motivation, resistance, flexibility, secondary gains, and desire to improve. ${ }^{20}$ In patients with mental retardation, when analysis is rendered impossible, analytic understanding may help. ${ }^{20}$

From a structural diagnostic point of view, Kernberg assesses the structure of the ego and superego, the nature of internalized object relations, and the nature of defensive behaviors in relation to libidinal and aggressive drive derivatives. According to the classification proposed by Kernberg 28,37,39-43 considering personality organization, psychoanalysis should be the treatment of choice in patients with a neurotic organization, whereas psychoanalytic psychotherapy would be the main indication in patients with a borderline organization, and support psychotherapy, in patients with a psychotic personality organization.

Keidann \& Dal Zot ${ }^{19}$ do not exclude the possibility of offering psychoanalytic psychotherapy to patients with diagnosis-based contraindications (Table 2), provided it is offered combined with other therapies, such as support therapy, behavioral therapies, use of psychopharmacological drugs, or hospital admission. The same opinion is shared by Eizirik \& Hauck, ${ }^{30}$ especially regarding the potential benefits of modified psychoanalytic interventions to patients with borderline personality disorder. ${ }^{30}$

Gabbard $^{38}$ contraindicates long-term therapy for obsessive-compulsive therapy, but alerts to the fact that dynamic therapy in these cases could contribute to treatment adherence and the way these patients deal with relationship problems. The author also states that, in the treatment of schizophrenic and bipolar patients, combined with the use of medication, psychodynamic understanding can be useful to assess resistance to improvement and the therapist's countertransference difficulties.

Empirical research has helped determine diagnostic categories for which psychoanalytic psychotherapy can be effective. A review conducted by the Research Committee of the International Psychoanalytical Association concluded that evidence suggesting the efficacy of this 
treatment modality in patients with moderate neurosis was consistent, differently from evidence in severe neurotic patients, which is less consistent. ${ }^{44}$ Prospective studies involving patients with personality disorders have shown substantial improvement in the groups treated with psychoanalytic psychotherapy. ${ }^{45-47}$ Specifically regarding borderline personality disorders, a psychodynamically oriented day treatment program has been analyzed, comprising group therapy and also individual sessions, with significantly better results associated with the treated group vs. the control group, and further gains during the follow-up period. ${ }^{48}$ ver Roth \& Fonagy, ${ }^{49}$ Leichsenring, ${ }^{8}$ and Leichsenring \& Rabung ${ }^{50}$ offer more detailed reviews of empirical studies investigating the effectiveness of psychoanalytic therapies in each diagnosis.

\section{Present moment in life}

Classically, starting analysis during the critical period of acute, situational, neurotic, or psychotic emotional symptoms is contraindicated. Dewald ${ }^{23}$ advocates that insight-oriented psychotherapy is usually indicated after reasonable disease stabilization. Zimerman, ${ }^{29}$ however, argues that this criterion is no longer valid, as it is now possible to start an analytic process with the simultaneous use of psychopharmacological drugs.

Fenichel ${ }^{20}$ argues that analysis should not be started when the patient presents an unfavorable life condition. For that author, people may be harmed by analysis and become sadder if they are living a situation that is incompatible with reward, and in whom neurosis offers a necessary illusion for survival. This is an important ethic implication in the consideration of indication and contraindication criteria that will be discussed below. When symptoms are urgent, e.g., suicidal ideation, analysis is also contraindicated. The same is true of severe speech impairments. Even though speaking may be replaced with writing in some cases, at least temporarily, each situation should be carefully analyzed.

Practical conditions are also necessary to ensure the patient's commitment to psychoanalytic treatment. In order to be indicated for insight-oriented psychotherapy, the patient has to be willing to undergo long-term treatment, have the necessary time and regularity, economic conditions, and the support of family members. ${ }^{23}$ The patient also needs to be able to maintain a job so as to afford a long-term treatment, ${ }^{27}$ and to be willing to invest time and money in the treatment. ${ }^{19,30}$

\section{Motivation for treatment}

The greater the patient's desire to change, the better the prognosis. Patients need to be motivated to face their resistances, and this evaluation should go beyond the patients' report: the analyst should be alert to the patients' unconscious motivations to face their resistances and overcome their disease. $20,24,25,27,28,30$ Sometimes patients do not show an explicit motivation for treatment at the beginning, and this situation is understood and accepted, but it may change over the course of therapy. ${ }^{23}$

Zimerman $^{29}$ contraindicates psychoanalytic treatment in cases showing unusual motivations. There are also those cases in which an evident secondary gain is associated with the disease; according to Greenson, ${ }^{24}$ these should be contraindicated for treatment.

Keidann \& Dal Zot ${ }^{19}$ suggest that the therapist should assess the patient's motivation based on the following aspects: 1) spontaneous search for treatment; 2) psychological nature of symptoms; 3) tendency to introspection and an honest, true report; 4) active participation in the treatment process, showing curiosity and a desire to understand him/herself; 5) responsibility to deal with difficulties; 6) realistic expectations in relation to analytically oriented psychotherapy; 7) willingness to invest time and money in the treatment.

Other aspects that should be taken into consideration in the analysis of the patient's motivation include the presence of complaints centered on him/herself and not on others, response to test interpretations, and punctuality to sessions.

\section{Ability to abstract, symbolize, and gain insight}

The more able or ready a patient is for introspection and for acquiring knowledge of his/her own emotional life and the emotional lives and reactions of others, the higher the likelihood of positive effects deriving from the therapeutic work. ${ }^{23}$ Tendency to introspection is also advocated by Keidann \& Dal Zot as an indication criterion, ${ }^{19}$ together with the ability to symbolize. ${ }^{29}$ Gabbard, ${ }^{27}$ in turn, refers to the ability to think in terms of analogy and metaphor, the ability to gain insight, and the use of reflexive responses to interpretation attempts as indication criteria for expressive treatments. Kernberg ${ }^{28}$ recommends psychoanalytic-based support psychotherapy in patients with a limited ability to gain insight. In sum, it seems necessary that the patient can think psychologically ${ }^{30}$ in order for psychoanalytic treatment to be indicated. Finally, patients should have at least average intelligence for insight-oriented therapies to be indicated. ${ }^{19,23,28}$

\section{Significant object relations}

In order to be indicated for analysis/psychoanalytic psychotherapy, the patient requires previous ability to 
establish and maintain emotionally significant bonds with other people. ${ }^{23,27,28,30}$

The establishment of at least one quality, emotionally significant object relation in the past is an indicator that this ability could be recovered through psychoanalytic psychotherapy. ${ }^{19,30}$ Fenichel ${ }^{20}$ advocates the need for patients to show traces of a good object relation to start analysis: when the basis of object relations is lacking, psychoanalysis is rendered inapplicable; where that basis is too poor, adaptations/changes in the technique are necessary.

\section{Defensive style}

Dewald $^{23}$ states that the higher the flexibility and variety of defensive behaviors available, the more able the patient will be to find effective integration models. More primitive defenses may represent a contraindication for insight-oriented therapies.

With regard to the patient's ability to control impulses, controversial results were found in the literature. Both Keidann \& Dal Zot ${ }^{19}$ and Gabbard ${ }^{27}$ advocate that the patient should have a previous ability to control impulses in order to start an insight-oriented treatment program. The prevailing defensive behavior (primitive vs. mature) toward impulse-related needs is considered by Kernberg ${ }^{28}$ as a major determinant in the indication of different psychoanalytic therapies. The impossibility to control life-threatening or therapythreatening behaviors contraindicates psychoanalytic psychotherapy. ${ }^{28}$ Eizirik \& Hauck, ${ }^{30}$ in turn, suggest that psychoanalytic psychotherapy could be indicated for patients unable to control their impulses, with a gradual development of this ability over the course of treatment.

\section{Psychic suffering}

Psychic suffering is closely related to motivation for treatment, and it is also an important aspect of the costbenefit analysis of a long-term treatment. Therefore, psychic suffering is a major determinant of whether psychoanalytic psychotherapy or analysis should be indicated to a certain patient. ${ }^{25,27}$

Psychic suffering has been termed differently by psychoanalytic authors. Fenichel, ${ }^{20}$ for example, discouraged the indication of analysis for neuroses of little importance (p. 642). Notwithstanding, the indication of psychoanalytic treatment based on psychic suffering broadens the discussion of clinical diagnoses. Even without a formal psychiatric diagnosis, individuals with dysfunctional life aspects would benefit significantly from the psychoanalytic method, ${ }^{20}$ as would also patients with a focal conflict expressed through interpersonal behavior symptoms that cause suffering. ${ }^{19}$
When assessing psychic suffering in a patient, a major aspect is countertransference response, which may be characterized by empathy/identification with or distance from the patient.

\section{Accessibility to the unconscious}

The indication and contraindication of psychotherapy should also be based on the patient's accessibility to the interpretations made by the analyst/therapist, rather than on the condition manifested by the patient. This criterion is primarily related with the patient's motivation, availability, courage, and ability to grant access to his/ her unconscious, for both the analyst and him/herself. ${ }^{29}$ For Glover, ${ }^{21}$ accessibility to the patient's unconscious depends on his/her transference potential.

The ability to counteract resistance is a classic indication criterion, as it suggests that the patient has a reasonable, cooperative ego, an essential ally in analytic treatment. 20

\section{Intact reality test}

Kernberg ${ }^{39-43}$ states that the degree of contact the patient has with reality is among the main criteria for indicating psychoanalytic treatment. Patients with major self-representation and object representation distortions, an impaired ability to distinguish between internal and external stimuli, and also those with an impaired ability to maintain empathy, would not be indicated for psychoanalysis, but could benefit from a modified psychoanalytic psychotherapy approach.

The intact reality test is also considered an indication criteria for psychoanalytic psychotherapy by Keidann \& Dal Zot, ${ }^{19}$ Gabbard, ${ }^{27}$ and Eizirik \& Hauck. ${ }^{30}$

\section{Other dynamic factors}

The broader scope of descriptive diagnosis, through the psychodynamic assessment of different personality traits, is essential in treatment indication, as it offers valuable information on mental functioning that it not covered by nosological diagnosis, centered on the description of symptoms. Psychodynamic assessment was operationalized with the creation of the Operationalized Psychodynamic Diagnosis (OPD), ${ }^{51-53}$ currently in its second version, however lacking validation for use in Brazil. This instrument contains five axes that assess different aspects: 1) illness experience and treatment assumptions; 2) interpersonal relationships; 3) conflict; 4) structure; and 5) traditional diagnosis (based on the International Classification of Diseases and the Diagnostic and Statistical Manual of Mental Disorders). Assessment of these psychodynamic dimensions 
would be essential to better understand the patient's personality, resulting in both greater adequacy of treatment indication and better planning and implementation of the psychotherapeutic or analytic process.

In addition to the factors already discussed, tolerance to anxiety and frustration are other important indication criteria found in the literature. ${ }^{19,23,25,27,28,30}$

Dewald ${ }^{23}$ highlights the need to assess two additional psychodynamic aspects. The first one is related to the id function: the more the conflict is focused on the phallic and oedipal phase, the better the prognosis, with insightoriented therapies being mostly indicated. The second aspect relates to the analysis of superego functions: extremely rigid individuals or those without internalized values and rules are poor candidates for insight-oriented treatment. For that author, the therapy process takes place through a therapeutic alliance between the healthy portions of the patient's ego and the therapist, referred to by Dewald as the ego energy.

Kaplan \& Sadock ${ }^{25}$ have also distinguished between indications and contraindications for analysis and psychotherapy. Analysis would be indicated in patients with unconscious conflicts that provoke signs, symptoms, or character/personality problems. Specifically, patients reporting previous failure of psychotherapy should be referred for analysis. Conversely, analysis would be contraindicated in patients who do not have a rational, cooperative ego, who do not present major suffering, in urgencies that do not allow to wait for the establishment of transference neurosis, or in unchangeable life conditions where treatment would become an even greater source of difficulty. Psychoanalytic psychotherapy, in turn, would be indicated in patients showing a mature personality, an ability to establish a therapeutic alliance, tolerance to frustration, and motivation, however with no indications for analysis.

Kernberg ${ }^{28}$ also differentiates between psychoanalysis and psychoanalytic psychotherapy: in psychoanalysis, it would be important to analyze the strength of ego, motivation, insight, introspection, secondary gains, intelligence and age; in psychoanalytic psychotherapy, contraindications would include (especially if combined), secondary gains, the impossibility to control lifethreatening or therapy-threatening behaviors, limited intelligence, significant antisocial characteristics, and a desperate life situation. In the absence of indications for analysis or psychoanalytic psychotherapy, support psychotherapy emerges as the treatment of choice. In this case, the patient's ability to commit so as to allow constant treatment and the absence of severe antisocial elements are the minimum requirements.

Eizirik \& Hauck $^{30}$ emphasized the need for a minimum level of ego integration for analysis to be indicated, because of the establishment of transference neurosis and the additional stress imposed by the analytic process on the individual. Etchegoyen ${ }^{26}$ also suggests that the patient needs to show a vocation for analysis (p. 30) in order to start psychoanalytic psychotherapy or analysis; dislocation has been referred to by Bion as the psychoanalytic function of personality.

Sometimes, patient characteristics are not clear in the first interviews. In these cases, despite some predictable inconveniences, many psychoanalysts advocate the combination of a proof analysis or test analysis, which consists of extending the initial interview for a relatively longer period, after which both the patient and the analyst will make a definitive decision regarding treatment. $20,25,29$ Other options suggested by Dewald ${ }^{23}$ include engaging in a temporary treatment program and expand the evaluation period, or testing surface interpretation during the initial interview, to evaluate how the patient responds.

\section{Therapist characteristics}

The contributions of the therapist to the outcome of psychoanalytic treatment can be grouped into three dimensions: the technique employed, his/her ability to use the technique, and his/her personal qualities, such as empathy, reception, and truthfulness. ${ }^{54}$ In effectiveness studies, it was possible to observe that, although some therapists have reached consistently better results, even those with a poor overall performance had had some patients with good outcomes. Moreover, it has been observed that some therapists reach better effects in some domains than others: some therapists cause a greater impact in reducing symptoms, whereas others are more successful in increasing the level of interpersonal functioning. ${ }^{55}$ Therefore, treatment effectiveness seems to be dependent not only on therapist experience and training, but also on his/her specific characteristics (sex, age, ethnic origin), combined with those of the patient, on his/her ability to adhere to the technique, and finally, on his/her competency in establishing a therapeutic alliance with patients. ${ }^{49}$

Etchegoyen ${ }^{26}$ takes an extreme position when referring to indication and contraindication criteria for psychoanalytic therapies: even though some patient characteristics knowingly influence the process, the analyst's ability to overcome his/her own personal difficulties and technical/ theoretical limitations are even more determinant. In other words, according to that author, the greater the analyst's plasticity, the more likely his ability to form a pair that meets the needs of the patient (the best pair would always be formed by the best analyst; p. 36).

Not all schools are that extreme, but the importance of therapist-related aspects in the indication of psychoanalytic treatment is widely advocated. Some 
intimate issues of the therapist his/herself are known to influence the indication of psychotherapy. These issues may influence the therapist in the sense of prescribing ambitious, long-term treatment programs for the ones he likes, and brief, little-contact programs for those he does not like. ${ }^{23}$ Dewald ${ }^{23}$ also emphasizes schedule availability and financial needs of the therapist as important determinants of treatment indication. Moreover, the therapist is able to improve treatment effectiveness in some types of patients. The higher the number of therapist-related unconscious factors involved in this process, the lower the chances that treatment will be focusing on the patient's needs. Therefore, Dewald ${ }^{23}$ attests to the importance of therapist self-knowledge when accepting a certain patient for treatment.

As the above considerations suggest, there may be contraindications for treatment with a certain therapist, as also proposed by Fenichel. ${ }^{20}$ When patient resistances come into contact with therapist resistances, the analytic process tends to stagnate. Therefore, it is of paramount importance that the analyst works to reduce his/her own blind spots in his/her personal analysis, as self-analysis of one's own limitations does not seem possible. ${ }^{20}$

Keidann \& Dal Zot ${ }^{19}$ have argued that a negative countertransference from the therapist toward the patient should be considered a contraindication for that specific case, and that the patient should be referred to another colleague.

Another aspect to be considered is the therapist's ability to plasticize the technique employed according to the needs and profile of each patient. Dewald ${ }^{23}$ and Gabbard 27,38 have made an outstanding contribution to this topic. Dewald argues that insight-oriented therapies offer more benefits than support psychotherapies, and should therefore be preferred. The most important issue consists of the therapist's ability to correctly identify patients who will benefit from an insightoriented approach, especially because these patients are very few (most people are more prone to receiving support treatment). By stating that, Dewald recognizes the high number of cases with contraindications for psychoanalysis or analytic therapies and advocates the therapist's ability to offer support interventions, based on a psychoanalytic understanding of the case. Indication criteria are relative, and no criterion alone can indicate or contraindicate the correct type of treatment (insight or support) for a given patient. The therapist should evaluate the characteristics of the patient and his/her own, e.g., personal values, rigidity, and time availability, when considering the possibility to indicate insight-oriented treatment. Finally, therapist self-knowledge of his/her own ability to treat certain cases should also be taken into consideration.
During the therapeutic process, there is a constant oscillation between moments at which the patient would benefit from interpretive (expressive) interventions and moments at which support interventions are more adequate. The indication for either approach can therefore change. ${ }^{23,27}$ The therapist can and should flexibilize the technique, using support interventions in cases showing chronic ego deficiency (poor control of impulses and anxiety, severe damage to object relations, and a poor ability to establish a therapeutic alliance) and acute regression of a healthy person experiencing a vital crisis $^{27}$; once the crisis is over, expressive interventions should prevail. ${ }^{27}$ Some patients with indications for analysis or long-term psychoanalytic psychotherapy may require support interventions to help them deal with structural deficiencies of their own self or when they show a weakened reflexive function. ${ }^{38}$

\section{Patient/therapist pair characteristics}

Up to the present moment, only two predictors of good outcomes after psychoanalytic treatment have been identified: a good alliance at the beginning of treatment and congruence between the topic of conflictive relations and that of interpretation contents. ${ }^{27,30}$ The interaction between the pair is therefore crucial for treatment effectiveness. The type of relationship produced when patient and therapist meet at the initial phases of the evaluation is uncertain, as the work field between both parties will develop gradually. ${ }^{27}$

Taking into consideration cases that do not evolve as expected according to formal indications, patients who adapt better to certain therapists, and pairs that modify their interaction over the course of treatment, it remains open to question whether it is actually valid to determine strict criteria for treatment indication. The psychoanalytic technique has gradually shifted from a focus almost exclusively centered on isolated patient and therapist characteristics to a focus more centered on the analytic field and its role in the healing process. The same is true of the discussion regarding treatment indications.

\section{The analytic field}

The concept of analytic field, first described by Baranger \& Baranger in 1961, takes into consideration the relational environment established between the patient and the analyst. It also covers transference and countertransference issues originated from the basic unconscious fantasy, which is a product of the field. The analytic field is therefore not a mere sum of the contributions of both the therapist and the patient, but 
rather a new structure with its own characteristics. ${ }^{56}$ The creation of the concept of analytic field increases the complexity of the analyst's work, as this new understanding suggests that both subjectivities (that of the patient and that of the analyst) are equally important in the process, mutually influencing each other and creating an intense emotional contact that will not only modify but also define advance or stagnation in the analytic process. ${ }^{57}$

It is from and through the analytic field that the therapist will become able to effectively interpret and, through a second look, make the field move and restructure the basic underlying fantasy. Thus, interpretations and the emotional experiences of the pair connect and change. Successive changes in the analytic field constitute the analytic therapeutic process.

Any encounter between two or more people is fruitful for the development of a relational field; however, for the establishment of a therapeutic analytic field, some other characteristics are necessary, for example a work contract, specific space and time limits, and an essential ambiguity, i.e., a guarantee that any experience, report, act, or event experienced in the field will be understood in its most diverse meanings, always lived "as if." This essential ambiguity also takes into consideration the therapist (eliminating the objective personality of the therapist from the analytic situation as much as possible), body ambiguity, space ambiguity, and time ambiguity. ${ }^{56}$

If the analytic field influences the analytic process and its development, it is important to consider to what degree it also relates with indications for analytically oriented psychotherapy, as treatment should be indicated or contraindicated before the analytic field is established and as the latter will always be changing. The notion of analytic field seems to require relativization of traditional indications and contraindications based on specific criteria (condition, age, ability to gain insight, etc.), as even patients lacking such "abilities" may find a suitable analyst and benefit from an analytically oriented treatment program based on the creation of a new emotional structure that will develop and evolve according to their abilities and needs. It is necessary to be attentive to variations in the field in order to understand the way how the pair moves and precisely indicate the most adequate method.

Therefore, the possibility of establishing an analytic field should be assessed when considering the indication of analytically oriented psychotherapy, and both the patient and therapist need to be able, willing, and motivated to experience a genuine, intimate emotional contact. The establishment of good object relations in the past is an indicator of such ability. Based on what will be experienced in the analytic field, it will be possible to detect the need and possibility of a certain pair to use a therapy with a more expressive or a more supportive approach. According to Baranger \& Baranger, ${ }^{56}$ a good analytic work in a given session depends on the congruence between the patient's and the therapist's basic fantasy, meaning that the analyst should be able to abdicate from his/her omnipotence, perceiving his/her own limitations and difficulties dealing with certain cases. In this context, it is important to distinguish between resistance difficulties of the pair and an inability to work together. The existence of a stronghold is inherent to the notion of psychoanalytic field. Such stronghold would be an unconscious structure assumed to protect the pair in an omnipotent way, preventing them from getting in contact with too primitive states, such as worthlessness, vulnerability, and abandonment; it refers to what the patient unconsciously does not want to put at risk and that is also painful for the analyst to face in his/herself and consequently in his/her patient. Therefore, it is likely that the stronghold will determine the therapeutic limits of each pair. ${ }^{57}$

Notwithstanding, it is important to emphasize that the creation of a stronghold is inherent to the therapeutic process and should not be seen as a criterion or even as a consequence of the indications or contraindications for psychotherapy; any pair, regardless of the adequacy of therapeutic indication, is subject to variations and constant changes that may emerge in these dynamic encounters between two people.

\section{Ethical implications and final considerations}

When discussing indications and contraindications for psychoanalytic treatment, some authors ${ }^{20,25}$ have argued and questioned to what degree it is valid to touch on certain conflicts when the therapist feels that the patient has extremely unfavorable or unchangeable life conditions, posing the risk of the treatment bringing even more suffering than the disease itself.

Another ethical issue that deserves to be discussed is the therapist's omnipotent belief that he/she is able to predict, based on initial evaluation findings, an adequate evolution of treatment even before starting it. The classic Freudian analogy of a chess game ${ }^{58}$ seems applicable here: only the beginning and the end of each match allow for systematic and exhaustive descriptions; the in-between period is marked by indetermination. Would it therefore be reasonable to contraindicate a potentially beneficial intervention before even trying it? From a different standpoint, would it be ethical to indicate a treatment without knowing for sure about its effectiveness for that specific case? Is it possible to be sure of the effectiveness of an intervention even when indications are based on rigorous objective criteria? A correct indication does 
not always guarantee good results. A patient may not survive cardiac surgery, for example, even if there are no doubts that the indication was correct. Is the same principle applicable to psychoanalytic science? It seems that, once again, the literature about indications and contraindications for psychoanalytic therapies leaves us with more questions than answers. ${ }^{38}$

Every patient seeking help presents a mixture of motivation and resistance to change, and it is not possible to separate these two factors. In this sense, would it really be essential for a good treatment progress that patients have some characteristics determined a priori? Considering characteristics such as the ability to control impulses, the ability to abstract, to gain insight, frustration tolerance, ego-dystonic conflict, and psychoanalytic function of personality, why cannot these be developed over the course of treatment? Fenichel ${ }^{20}$ advocates the existence of a preanalytic phase, whose aim would be to prepare the ego for analysis in cases of doubtful indication.

With regard to therapist-related factors, does not each therapist have his/her own contraindication criteria (based on previous experience, theoretical conception, personal analysis of own blind spots, object relations)? Perhaps each therapist, and not theory as a whole, should determine his/her technical limits and use them as a criterion when indicating or contraindicating therapies to each patient.

At present, with the advance of biological treatments, an increasing number of possibilities (and ethical obligations) emerge to combine different modes of treatment in the same patient. Combined treatment seems to be a possible solution for patients without a classic indication for psychoanalytic treatment. Symptomatic relief through the use of medication may contribute to the development of psychoanalytic treatment, and the latter may also improve compliance with pharmacological treatment in some patients.

There are also patients who try, at first and with no success, other therapies more commonly indicated for their condition. Assessing the success or failure of previous treatment attempts is another valuable ethical criterion to be taken into consideration.

As can be seen in clinical practice (and in line with Dewald's proposition), insight-oriented therapy is valid in some cases, in spite of a poor initial prognosis. In our opinion, treatment effectiveness in these cases depends on different factors: 1) therapist's interest in treating the case; 2) recognition of the limits and resources of the therapist and of the technique employed; 3) ability to flexibilize the technique, making it compatible with the patient's problem; 4) ethical conduct, i.e., not offering treatments based on therapist needs (especially financial ones); 5) case planning (anticipation of possible transference, examination of the pair's motivation and availability for that treatment); 6) formal supervision, especially in severe cases or those with doubtful indication; 7) constant search for improvement of psychotherapy theory and practice, updates and revisions.

According to Malan \& Selva, ${ }^{59}$ short-term psychoanalytic psychotherapy would be indicated in any patient able to withstand the anxiety of the first interview. In other words, the characteristics of the therapeutic process, and not only initial perceptions of the evaluation phase, should be carefully considered. We strongly believe that psychoanalytic treatment in general could also be indicated under the same conditions.

In Etchegoyen's words, when we take over a patient, we should think that we are taking over many patients, and that these many patients, or our real patient, will demand that we are all possible analysts (p. 38). ${ }^{26}$

\section{References}

1. Jung SI, Fillippon AP, Nunes ML, Eizirik CL. História recente e perspectivas atuais da pesquisa de resultados em psicoterapia psicanalítica de longa duração. Rev Psiquiatr Rio Gd Sul. 2006;28:298-312.

2. Jung SI, Nunes LT, Eizirik CL. Avaliação de resultados da psicoterapia psicanalítica. Rev Psiquiatr Rio Gd Sul. 2007;29:184-96.

3. Knijnik DZ, Kapczinski F, Chachamovich E, Margis R, Eizirik $\mathrm{CL}$. Psicoterapia psicodinâmica em grupo para fobia social generalizada. Rev Bras Psiquiatr. 2004;26:77-81.

4. Rosenthal RJ. Psicoterapia psicodinâmica e o tratamento do jogo patológico. Rev Bras Psiquiatr. 2008;30(suppl 1):S41-50.

5. Grande T, Dilg R, Jakobsen T, Keller W, Krawietz B, Langer $M$, et al. Differential effects of two forms of psychoanalytic therapy: results of the Heidelberg-Berlin study. Psychother Res. 2006;16:470-85.

6. Freedman N, Hoffenberg JD, Vorus N, Frosch A. The effectiveness of psychoanalytic psychotherapy: the role of treatment duration, frequency of sessions, and therapeutic relationship. J Am Psychoanal Assoc. 1999;47:741-72.

7. Kachele H. [Psychotherapy under evaluation]. Psychother Psychosom Med Psychol. 1998;48:77.

8. Leichsenring F. Are psychodynamic and psychoanalytic therapies effective? A review of empirical data. Int J Psychoanal. 2005;86:841-68.

9. Rudolf G, Manz R, Ori C. [Results of psychoanalytic therapy]. Z Psychosom Med Psychoanal. 1994;40:25-40.

10. Kachele $\mathrm{H}$. Clinical and scientific aspects of the UIm process model of psychoanalysis. Int J Psychoanal. 1988;69:65-73.

11. Sanderson WC. The case for evidence-based psychotherapy treatment guidelines. Am J Psychother. 1998;52:382-7.

12. Kachele $H$, Porzsolt F. [Ethics and/or evidence-based psychotherapy--a challenge]. Psychother Psychosom Med Psychol. 2000;50:37.

13. Sanderson WC. Why we need evidence-based psychotherapy practice guidelines. WebMD. Medscape Gen Med. 2002;4(4). http://www.medscape.com/viewarticle/445080

14. Watzke $B$, Rueddel $H$, Juergensen $R$, Koch $U$, Kriston $L$, Grothgar B, et al. Effectiveness of systematic treatment selection for psychodynamic and cognitive-behavioural therapy: randomised controlled trial in routine mental healthcare. Br J Psychiatry. 2010;197:96-105.

15. Fonagy P. Psychotherapy research: do we know what works for whom? Br J Psychiatry. 2010;197:83-5. 
16. Hauck S, Kruel L, Sordi A, Sbardellotto G, Cervieri A, Moschetti $L$, et al. Fatores associados a abandono precoce do tratamento em psicoterapia de orientação analítica. Rev Psiquiatr Rio Gd Sul. 2007;29:265-7.

17. Freud S [1905]. Sobre a psicoterapia. In: Strachey J, editor. Um caso de histeria, Três ensaios sobre sexualidade e outros trabalhos. Edição Standard Brasileira das Obras Psicológicas Completas de Sigmund Freud. VII. $2^{a}$ ed. Rio de Janeiro: Imago; 1987. p. 239-52.

18. Fonagy P. Estudos sobre a efetividade das psicoterapias. In: Eizirik C, Aguiar R, Schestatsky S, editors. Psicoterapia de orientação analítica: fundamentos teóricos e clínicos. Porto Alegre: Artmed; 2005. p. 424-61.

19. Keidann C, Dal Zot J. Avaliação. In: Eizirik C, Aguiar R, Schestatsky S, editors. Psicoterapia de orientação analítica: fundamentos teóricos e clínicos. Porto Alegre: Artmed; 2005. p. $193-205$.

20. Fenichel O. Teoría psicoanalítica de las neurosis. Buenos Aires: Paidós; 1966.

21. Glover E. The technique of psycho-analysis. London: Baillière, Tindall \& Cox; 1955.

22. Nacht $S$, Lebovici $S$. Indicaciones y contraindicaciones del psicoanálisis en el adulto. In: Gemelli $A$, editor. El psicoanálisis hoy. Buenos Aires: Dom Bosco; 1958. p. 44-79.

23. Dewald P. Indicações para psicoterapia. Psicoterapia: Uma abordagem dinâmica. Porto Alegre: Artes Médicas; 1989. p. 133-61.

24. Greenson R. A técnica e a prática da psicanálise. Rio de Janeiro: Imago; 1981.

25. Kaplan H, Sadock B. Compêndio de psiquiatria dinâmica. $3^{a}$ ed. Porto Alegre: Artmed; 1984.

26. Etchegoyen H. Fundamentos da técnica psicanalítica. Porto Alegre: Artmed; 2004

27. Gabbard G. Tratamentos em psiquiatria dinâmica. Psiquiatria psicodinâmica na prática clínica. Porto Alegre: Artmed; 2006. p. 79-102.

28. Kernberg O. A psicanálise, a psicoterapia psicanalítica e a psicoterapia de apoio: controvérsias contemporâneas. Agressividade, narcisismo e auto-destrutividade na relação psicoterapêutica. Lisboa: Climepsi; 2006. p. 117-44.

29. Zimerman D. Manual de técnica psicanalítica: uma re-visão. Porto Alegre: Artmed; 2004.

30. Eizirik C, Hauck S. Psicanálise e psicoterapia de orientação analítica. In: Cordioli $A$, editor. Psicoterapias: abordagens atuais. $3^{a}$ ed. Porto Alegre: Artmed; 2007. p. 151-66.

31. Bergeret J. A personalidade normal e patológica. $3^{a}$ ed. Porto Alegre: Artmed; 1998.

32. Abraham K. La aplicabilidad del tratamiento psicoanalítico a los pacientes de edad avanzada. In: Abraham $\mathrm{K}$, Jones $\mathrm{E}$, editors. Psicoanálisis clínico. Buenos Aires: Paidós; 1959. p. 238-42.

33. Segal $\mathrm{H}$. Fear of death - Notes on the analysis of an old man. Int J Psychoanal. 1958;39:178-81.

34. Woods $R$, Roth $A$. Effectiveness of psychological interventions with older people. In: Roth A, Fonagy P, editors. What works for whom? A critical review of psychotherapy research. 2nd ed. New York: Guilford Press; 2005. p. 425-46.

35. Stone $L$. The widening scope of indications for psychoanalysis. J Am Psychoanal Assoc. 1954;2:567-94.

36. Zetzel $E$. The analytic situation. In: Litman $R$, editor. Psychoanalysis in the Americas. New York: International Universities Press; 1964. p. 86-106.

37. Kernberg O. Desordenes fronterizos y narcisismo patológico. Buenos Aires: Paidós; 1975.

38. Gabbard G. Psicoterapia psicodinâmica de longo prazo. Porto Alegre: Artmed; 2005.

39. Kernberg O. La teoría de las relaciones objetales y el psicoanálisis clínico. Buenos Aires: Paidós; 1976.

40. Kernberg O. O mundo interior e a realidade exterior: teoria aplicada às relações objetais. Rio de Janeiro: Imago; 1980.

41. Kernberg O. Patologia borderline e alternativas psicoterápicas. Psicoterapia psicodinâmica de pacientes borderline. Porto Alegre: Artes Médicas; 1991. p. 13-21.
42. Kernberg O. Diagnóstico estrutural. Transtornos graves de personalidade: estratégias psicoterapêuticas. Porto Alegre: Artes Médicas; 1995. p. 5-24.

43. Kernberg $O$. Who are the patients: diagnostic issues. In: Yeomans F, Clarkin J, Kernberg O, editors. A primer of transference-focused psychotherapy for the borderline patient. Northvale: Aronson; 2002. p. 3-38.

44. Jones $E$, Kächele $H$, Krause $R$, Clarkin J, Perron $R$, Fonagy $\mathrm{P}$, et al. An open door review of outcome studies in psychoanalysis. 2nd ed. Fonagy $\mathrm{P}$, editor. London: International Psychoanalytical Association; 2002.

45. Hoglend P. Personality disorders and long-term outcome after brief psychodynamic psychotherapy. J Pers Disord. 1993; 7:168-81.

46. Monsen J, Odland T, Faugli A, Daae E, Eilertsen DE. Personality disorders and psychosocial changes after intensive psychotherapy: a prospective follow-up study of an outpatient psychotherapy project, 5 years after end of treatment. Scand J Psychol. 1995;36:256-68.

47. Monsen JT, Odland T, Faugli A, Daae E, Eilertsen DE. Personality disorders: changes and stability after intensive psychotherapy focusing on affect consciousness. Psychother Res. 1995;5:33-48.

48. Bateman A, Fonagy P. Effectiveness of partial hospitalization in the treatment of borderline personality disorder: A randomized controlled trial. Am J Psychiatry. 1999;156:1563-9.

49. Roth A, Fonagy P. The contributions of therapists and patients to outcome. In: Roth $A$, Fonagy $P$, editors. What works for whom? A critical review of psychotherapy research. 2nd ed. New York: Guilford Press; 2005. p. 447-78.

50. Leichsenring $F$, Rabung $S$. Effectiveness of long-term psychodynamic psychotherapy - a meta-analysis. J Am Med Assoc. 2008;300:1551-65.

51. Cierpka M, Grande T, Rudolf G, von der Tann M, Stasch M. The operationalized psychodynamic diagnostics system: clinical relevance, reliability and validity. Psychopathology. 2007; 40:209-20.

52. Risl E, Von de Tann M. Operationalized Psychodynamic Diagnosis (OPD-2): manual of diagnosis and treatment planning. OPD Task Force, editor. Cambridge: Hogrefe \& Huber; 2008.

53. Pérez F, Alvarado L, De la Parra G, Dagnino P. Diagnóstico psicodinámico (OPD-2): evaluación preliminar de la validez y confiabilidad inter-evaluador. Rev Chil Neuro-Psiquiatr. 2009;47:271-8.

54. Schaffer ND. Multi-dimensional measures of therapists behavior as a predictor of outcome. Psychol Bull. 1982;92:670-81.

55. Luborsky L, Critschristoph P, McLellan AT, Woody G, Piper W, Liberman $B$, et al. Do therapists vary much in their success? Findings from four outcome studies. Am J Orthopsychiatry. 1986;56:501-11.

56. Baranger M, Baranger W. La situación analítica como campo dinámico. Rev Uruguaya Psicoanal. 1961;4:3-54.

57. Knijnik J, Rispoli A, Tofani AC, Mello C, Rubin L, Eizirik C. Baluarte, surpresa e comunicação no campo analítico. Rev Bras Psicanal. 2012;46:150-61.

58. Freud S [1913]. Sobre o início do tratamento (Novas recomendações sobre a técnica da psicanálise I). In: Strachey J, editor. O caso de Schreber, Artigos sobre técnica e outros trabalhos. Edição Standard Brasileira das Obras Psicológicas Completas de Sigmund Freud. XII. 2a ed. Rio de Janeiro: Imago; 1987. p. 163-90.

59. Malan D, Selva P. Psicoterapia dinâmica intensiva breve: um método inovador. Porto Alegre: Artmed; 2008.

\section{Correspondence}

Marina Gastaud

Rua Comendador Caminha, 312/205

90430-030 - Porto Alegre, RS - Brazil

Tel.: +55 (51) 3346.1664

E-mail: marinagastaud@hotmail.com 